\section{The World of Science}

By Dr. F. Sherwood Taylor. Pp. xvi $+1064+48$ plates. (London : William Heinemann, Ltd., 1936.) 8s.6d. net. To those who are fond of encyclopædic omnibus volumes this book will give pleasure. Its avowed purpose is "to answer in simple terms the questions which the ordinary man and woman ask about living creatures, the world and the mechanical devices daily encountered by all". One must admire the successful conclusion of the immense task that the preparation of this book must have proved to the author and his assistants. Nevertheless, parts of the book seem to indicate that the weariness known to all authors of large volumes must sometimes have unwittingly crept over Dr. Taylor, and one can well imagine him struggling with the gigantic array of knowledge represented by the whole of science.

The style adopted does not, in general, make for easy reading, the sentences being, for the most part, short and jerky. The various divisions of the branches of science are set out in tabular form on p. 12. In such an up-to-date book we are surprised at the omission of biophysics, especially as biochemistry is included. There are a few inconsistencies in the book itself. On p. 295 it is stated : "It was a longish step to show that matter of all kinds was made up of nothing but these electrons and positive charges", but on p. 531 we read that "atoms are composed only of three things, electrons, protons, and neutrons". The statement on p. 421 that "ultrasonic waves are transmitted very much as light" is misleading. True ultrasonics behave to some extent in a similar way to light, but the mode of transmission is fundamentally different.

It is unfortunate that some of the diagrams have been reduced so much as to detract considerably from their value. Chemical substances and reactions are frequently shown diagrammatically as groups of spheres representing atoms, in the manner used to represent crystal structure. The advantage of this over the more usual chemical formulæ is open to question, for it seems liable to lead to misconceptions.

Despite these criticisms, however, this book contains a vast store of knowledge, accurately presented, and will form a useful addition to the "ordinary man's" library, and the index will enhance its value as a reference book.

H. R. LANG.

\section{Battlefield of the Gods :}

Aspects of Mexican History, Art and Exploration. By Pál Kelemen. Pp. $212+61$ plates. (London : George Allen and Unwin, Ltd., 1937.) 10s. 6d. not. "BAtTlefield of the Gods" should not be passed. over lightly as a travel book of the usual type. The author, it is true, is neither archæologist nor ethnologist and in his description of such of the archæological sites of Mexico and Yucatan as were visited by him, there is nothing new in the way of fact; but he has the trained eye of an artist, and he has pondered to some effect the place of art as a functional element in culture. Hence he is able to bring out the significance of the art and architecture of the ancient peoples of Central America as an expression of their racial history, developing under the influence of their environment. It must be counted as among the more illuminating features of this book that the author's review of post-Conquest development and his studies of ecclesiastical architecture and the Christian religion, as it was adopted by the native, as well as his incidental glimpses of the native mind as it exists to-day, demonstrate vividly how Maya, Aztec and Spaniard have blended to produce what is most characteristic and distinctive in the modern civilization of Central America. In short, in a series of impressionistic sketches he indicates the trend of that continuity of cultural development from preConquest days, of which the evidence is being collected, more scientifically perhaps, but not more convincingly, by the organized research of the Carnegie Institution of Washington.

It should be added that some remarkable examples of post-Conquest ecclesiastical art are figured and described here, which have not previously been published. This book should do much to convince English readers of the interest of a branch of archæology which, unfortunately, has too few supporters in Great Britain.

\section{The Statesman's Year-Book :}

Statistical and Historical Annual of the States of the World for the Year 1937. Edited by Dr. M. Epstein. Seventy-fourth annual publication, revised after Official Returns. Pp. xxxvi+1502. (London : Macmillan and Co., Ltd., 1937.) 20s. net.

FEW volumes cover a more comprehensive field than this annual, which as usual has been revised up to the end of March in the year of issue. Government, area, population, education, finance, production, commerce, communication and many other topics are descriptively and statistically treated for every State in the world. In addition, there is information on currency, weights and measures and even names of diplomatic representatives, and long lists of authoritative books of reference. The British Empire and the United States of America receive the fullest treatment and occupy nearly half the volume, which despite its many pages occupies a remarkably small bulk. An exhaustive index facilitates reference. As usual, two coloured maps are included: this year they show respectively the Sanjak of Alexandretta in relation to Syria, and Abyssinia with surrounding territories. A number of tables give world production of several important commodities and particulars of fleets and merchant shipping.

\section{Builders' Estimates and Pricing Data :}

their Preparation and Analysis. By Henry A. Mackmin. (The Directly-Useful Technical Series.) Second edition, revised and enlarged. Pp. xii +227 . (London : Chapman and Hall, Ltd., 1936.) 12s. 6d, net.

THIs work is the third edition of a book first published in 1926 and incorporates not only new matter on recent developments in building construction, but also the methods of estimating used in the Midlands and the north, as well as in London and the south. It is extremely readable, and can be suggested as well suited to those engaged in the technical side of building generally.
B. H. K. 